\title{
Perception of Caregivers on Health and Oral Hygiene Care of Institutionalized Impaired Elderly
}

\author{
Percepción de Cuidadores Sobre Salud y Cuidados de \\ Higiene Oral de Ancianos Discapacitados institucionalizados
}

\begin{abstract}
Deiziane Rocha Marques*; Felipe de Souza Matos*; Tito Marcel Lima Santos*; José Lucas Sani de Alcântara Rodrigues $^{* *}$; Luiz Renato Paranhos*; Fábio Martins* \& José Rogério Vieira de Almeida*
\end{abstract}

MARQUES, D. R.; MATOS, F. S.; SANTOS, T. M. L.; RODRIGUES, J. L. S. A.; PARANHOS, L. R.; MARTINS, F. \& VIEIRA DE ALMEIDA, J. R. Perception of caregivers on health and oral hygiene care of the institutionalized impaired elderly. Int. J. Odontostomat., 10(3):443-448, 2016.

\begin{abstract}
This study assessed the perception of caregivers on oral health of institutionalized impaired elderly, and the care provided for them in oral hygiene and prosthetic rehabilitation. A descriptive observational study was developed with caregivers of 32 institutionalized impaired elderly, in the state of Sergipe, Brazil. Data collection was performed by interviewing the caregivers, researching records of the Institution, and by clinical examination of the oral cavity of the elderly during a period between the months of March and May, 2013. Data were analyzed by descriptive statistics of absolute frequency $(n)$ and relative frequency (\%). All of the elderly presented partial (50\%) or total (50 \%) tooth losses, and only 28.1 $\%$ wore removable denture. The prosthetic devices and remaining teeth of the elderly were cleaned with only toothbrush and toothpaste $(100 \%)$, with different daily frequencies among caregivers and no dentist instruction. The majority of caregivers was satisfied with the oral hygiene of the elderly $(75 \%)$ and the oral hygiene method $(96.9 \%)$ used, and showed no interest in learning new methods (81.3\%). The caregivers have an inadequate perception on oral health of the elderly population investigated, and oral hygiene care provided to the elderly is precarious.
\end{abstract}

KEY WORDS: dental assistance for the elderly, caregivers, oral hygiene, long stay institution for the elderly, oral health.

\section{INTRODUCTION}

The Brazilian population, as in other countries, is currently going through an accelerated aging process. The number of inhabitants aged 60 years or older has grown exponentially, while mortality and birth rates have dropped significantly, causing an inversion process on the population pyramid of the country (Colussi et al., 2004; Brazilian Institute of Geography and Statistics, 2010; Mafra, 2011; Almeida et al., 2015); also quality and care for the health of the elderly population have been through major transformations. The health care of the elderly has become a public health centerline, where humanization and full-time home care have extensively stood out (Pereira et al., 2011; Magalhães et al., 2015).

Aging is an organic and continuous process, but it entails some restrictions, especially in cognitive and physical contexts, as well as producing a certain vulnerability of the organism, making it more susceptible to diseases. Dementia syndromes are described as diseases that produce progressive and persistent restrictions of multiple intellectual activities such as memory, ability to communicate, learning, and limitation of physical functions and personal care (Maia et al., 2004; Benedetti et al., 2008; Ferreira et al., 2014).

Hence, caring for the elderly becomes a peculiar task that may represent a very difficult activity for the family to perform in their own home. Transferring the elderly from their home to a Long Stay Institution for the Elderly (LSIE) is an increasingly frequent practice, especially for elderly people who present some degree of intellectual or physical limitation. The home exchange and the complete convivial

\footnotetext{
* Department of Dentistry, Federal University of Sergipe, Aracaju, Sergipe, Brazil.

"* Health Department, School of Dentistry, Feira de Santana State University, Bahia, Brazil.
} 
modification with their family is a great challenge for the elderly, so that special monitoring, psychological care, and multidisciplinary support are required (Sá et al., 2012).

Depending on the type of service of the LSIE, there is a variation of the minimum staff; however, this staff does not usually include the presence of a dentist (Sá et al.). Thus, it is up to the Institution to provide the participation of Dentistry professionals for the required support of the institutionalized elderly population, planning on full-time and humanized care services, both for oral and general health (Sá et al., Ferreira et al., 2014).

The caregiver for the elderly is a professional that, in the home environment or in a long stay institution, performs monitoring activities and provides exclusive assistance to the elderly, such as health preventive care, emotional support, and assistance for mobility and the performance of personal hygiene and nutrition routines. However, the neglect of these professionals regarding oral hygiene habits of the elderly, for the lack of both professional education and information on the subject, is quite present (Ferreira et al., 2011; Reis et al., 2011; Sá et al.).

Edentulism stands out as the main harm to oral health in the institutionalized elderly (Costa et al., 2010; Haikal et al., 2011; Ferreira et al. 2011; Martins et al., 2014), consequently having a negative impact on their life, which triggers a series of disorders that affect digestion, gustation, and pronunciation. Edentulism also condones the unfavorable impact on self-satisfaction of the elderly with their oral and general health, making dental prosthetic rehabilitation essential for reestablishing oral conditions and social relations (Rosa et al., 2008; Rigo et al., 2015). In this context, this study aimed to investigate the perception of caregivers on oral health of the institutionalized impaired elderly and to assess the care provided to them in oral hygiene and for prosthetic rehabilitation.

\section{MATERIAL AND METHOD}

The Ethics Committee on Human Research approved this study (Certificate of Ethical Consideration Presentation: 12699113.7.0000.5546), ensuring the present research has followed the legal and ethical principles.
Type of study, sample characteristics, and location. The research was developed on the descriptive observational study model, and data collection was performed by interviewing the caregivers of the elderly, researching records of the Institution, and by clinical examination of the oral cavity of the elderly, in a period between the months of March and May, 2013. The sample included caregivers of 32 institutionalized impaired elderly, with no gender restriction, living in the state of Sergipe, Northern Brazil. The state of Sergipe has an estimated population of 2.068.017 inhabitants, distributed in a territory area of 21.918.493 $\mathrm{Km}^{2}$ according to the last demographic census from the Brazilian Institute of Geography and Statistics (IBGE) of 2010.

Eligibility and exclusion criteria. Included in the study were only caregivers of elderly people over 60 years old, considered impaired by the cognitive and motor standpoint, that is, those who did not present understanding ability to answer the questionnaire and who depended on their caregivers to perform daily health and oral hygiene care. As for the characteristics of caregivers, only those who had monitored the respective elderly person for at least six months participated in the study, so to ensure sufficient knowledge about the elderly to answer the questionnaire. This information was obtained by researching records of the Institution.

Data collection and analysis. A structured questionnaire with 19 objective questions was individually applied to the respective caregiver of each elderly person by a previously trained examiner, with estimated time of 20 minutes for each interview. The questionnaire included sociodemographic characteristics (gender and age) and clinical characteristics (tooth losses and use of removable prosthesis), as well as the perception of caregivers on oral health conditions of the elderly and oral hygiene care provided to them. The sociodemographic and clinical data of the elderly were confirmed based on records of the Institution and the clinical examination of their oral cavities, respectively. Clinical examinations were performed in the Institution, under natural light, through visual tactile inspection, and aided by flat mouth mirrors. The examiner was attired according to the norms of crossed infection control (use of lab coat, protective goggles, head cover, mask, and disposable gloves).

Data obtained from the application of structured questionnaires were tabulated and analyzed by absolute frequency (n) and relative frequency (\%). For 
MARQUES, D. R.; MATOS, F. S.; SANTOS, T. M. L.; RODRIGUES, J. L. S. A.; PARANHOS, L. R.; MARTINS, F. \& VIEIRA DE ALMEIDA, J. R. Perception of caregivers on health and oral hygiene care of the institutionalized impaired elderly. Int. J. Odontostomat., 10(3):443-448, 2016.

data analysis, the Statistics, version 5.0 software (StatSoft Inc., Tulsa, USA) was used.

\section{RESULTS}

Of the 32 impaired elderly assessed, 15 (46.9 $\%)$ were men and 17 (53.1\%) were women. The average age of the elderly was 84 years and two months, with minimum age of 62 years and maximum age of 106 years. Among these, 16 (50\%) were completely edentulous, 16 (50\%) were partially edentulous, and only nine $(28.1 \%)$ used removable partial and/or complete denture. Table I shows the characteristics related to the 32 elderly by the perception of the caregivers. Tables II and III show the characteristics related to the nine elderly who wore removable prosthesis, and the attitudes of their caregivers facing oral and prosthetic hygienization, respectively.

Table I Characteristics related to the 32 elderly assessed, by the perception of caregivers.

\begin{tabular}{lcccc}
\hline \multicolumn{1}{c}{ Characteristics } & \multicolumn{1}{c}{ Yes } & \multicolumn{2}{c}{ No } \\
& $\mathbf{n}$ & \% & $\mathbf{n}$ & \% \\
\hline Wears removable denture & 9 & 28.1 & 23 & 71.9 \\
Regularly visits or is visited by a dentist & 10 & 31.3 & 22 & 68.8 \\
Received dentist instructions regarding oral hygiene and health care & 0 & 0.0 & 32 & 100.0 \\
Is satisfied with the oral health of the elderly & 24 & 75.0 & 8 & 25.0 \\
Considers the oral hygiene method effective and adequate & 31 & 96.9 & 1 & 3.1 \\
Is interested in learning other oral hygiene methods & 6 & 18.8 & 26 & 81.3 \\
Hygiene care of the remaining teeth & & & & \\
Toothbrushing & 16 & 50.0 & \\
Completely edentulous & 16 & 50.0 & &
\end{tabular}

Table II Characteristics related to the nine elderly who wore removable prosthesis and attitudes of their caregivers.

\begin{tabular}{|c|c|c|c|c|}
\hline \multirow{2}{*}{ Characteristics } & \multicolumn{2}{|c|}{ Yes } & \multicolumn{2}{|c|}{ No } \\
\hline & $\mathbf{n}$ & $\%$ & $\mathbf{n}$ & $\%$ \\
\hline The elderly sleeps with the removable dentu re & 7 & 77.8 & 2 & 22.2 \\
\hline $\begin{array}{l}\text { The elderly received dentist instruction regarding the form or means of maintaining the } \\
\text { prosthesis outside the mouth, while institutionalized }\end{array}$ & 0 & 0.0 & 9 & 100.0 \\
\hline $\begin{array}{l}\text { The elderly received dentist instruction regarding visiting the dentist pe riodically, while } \\
\text { institutionalized }\end{array}$ & 0 & 0.0 & 9 & 100.0 \\
\hline The caregiver received dentist instruction regarding prosthesis hygienization & 3 & 33.3 & 6 & 66.7 \\
\hline Removes the prosthesis from the mouth of the elderly to perform hygienization & 9 & 100.0 & 0 & 0.0 \\
\hline $\begin{array}{l}\text { After removing the prosthe sis for hygienization, toothbrushes the mouth and remaining } \\
\text { teeth of the elderly }\end{array}$ & 8 & 88.9 & 1 & 11.1 \\
\hline
\end{tabular}

Table III Characteristics related to oral hygiene and prosthetic care reported by the caregivers.

\begin{tabular}{|c|c|c|}
\hline Characteristics & $\mathbf{n}$ & $\%$ \\
\hline \multicolumn{3}{|c|}{ Number of times per day of prosthesis hygienization } \\
\hline 1 & 4 & 44.4 \\
\hline 2 & 2 & 22.2 \\
\hline 3 & 1 & 11.1 \\
\hline 4 & 2 & 22.2 \\
\hline \multicolumn{3}{|l|}{ Means of prosthesis hygienization } \\
\hline Toothbrush, water, and toothpaste & 9 & 100.0 \\
\hline \multicolumn{3}{|c|}{ Type of toothbrush used for prosthesis hygienization } \\
\hline Soft & 8 & 88.9 \\
\hline Unknown & 1 & 11.1 \\
\hline \multicolumn{3}{|l|}{ Hygiene care of the remaining teeth } \\
\hline Toothbrushing & 5 & 55.6 \\
\hline Completely edentulous & 4 & 44.4 \\
\hline
\end{tabular}


MARQUES, D. R.; MATOS, F. S.; SANTOS, T. M. L.; RODRIGUES, J. L. S. A.; PARANHOS, L. R.; MARTINS, F. \& VIEIRA DE ALMEIDA, J. R. Perception of caregivers on health and oral hygiene care of the institutionalized impaired elderly. Int. J. Odontostomat., 10(3):443-448, 2016.

\section{DISCUSSION}

The present study reports the perception of caregivers on oral health of the institutionalized impaired elderly, as well as oral hygiene care provided to them in a philanthropic Institution in the state of Sergipe, Brazil. The Institution was chosen because of the representativity of the sample among the ones available in the state. Most of the elderly were women with average age of approximately 84 years. Sá et al., through a quantitative approach performed with subjects aged 59 years and older, dependent and/or independent, living in a LSIE in the state of Rio de Janeiro, Brazil, noticed a compatible proportion with the results of the present study, where the number of elderly women $(62.06 \%)$ was higher than men. Such observation may be related to the higher life expectancy of women, who culturally present more health self-care, and consequently to male overmortality.

Dependence and cognitive impairment are factors that can aggravate oral diseases and reinforce inadequate oral hygiene care. Physical or visual limitation and the presence of chronic diseases that prevent the elderly from performing proper self-care usually contribute to a greater need for assistance in daily tasks (Hopcraft et al., 2012). This situation was confirmed in the Institution researched, where from the total of elderly people living in the nursing home, $57 \%$ participated in this research, meaning they depended on their caregivers to answer the questionnaire applied, as well as to perform daily activities.

An analytical cross-sectional study performed in Montes Claros, state of Minas Gerais, Brazil found higher prevalence of edentulism in the elderly with cognitive impairment, and endorsed higher DMFT index value for the same elderly people, highlighting the number of teeth lost, which corresponded to more than $90 \%$ of the total index (Ferreira et al., 2014). This proved the correlation of cognitive limitations as conditioning factors for oral problems, especially the loss of dental elements.

In this research, all of the elderly presented partial $(50 \%)$ or total $(50 \%)$ tooth losses, and only $28.1 \%$ wore removable dentures, showing a precarious situation in their oral health status. Similarly, studies such as Frare et al. (1997) showed, through home survey for data collection of oral condition, a reality where a significant portion of the elderly $(64.6 \%)$ were edentulous. A study performed in long stay institutions for the elderly revealed an even worse reality, where $74.9 \%$ of the elderly living in the city of Belo Horizonte, Brazil, were completely edentulous (Ferreira et al., 2009).

Similar rates of edentulism were also found among the institutionalized elderly on researches in Brazilian cities and states, such as by Reis et al. (2005) in Goiás, with $69.2 \%$ rate of edentulous people; Saliba et al. (1999) in Araçatuba (69 \%); Carneiro et al., also in 2005, in São Paulo, where 68.3 \% of the interviewed elderly were edentulous; Gaião et al. (2005) in Fortaleza, observed that $58.1 \%$ of the elderly were edentulous; and Haikal et al., in the state of Minas Gerais, identified edentulism in $57.7 \%$ of the elderly studied. Other studies found mean of 2.5 and 5.0 remaining teeth, respectively, in the institutionalized elderly (Carneiro et al.; Gaião et al.). The disregard with rehabilitation and oral health, evidenced in this research by the high rate of edentulous people with no prosthetic rehabilitation, was also reported in other studies such as by Ferreira et al. (2008), in Belo Horizonte, Brazil. This reality observed in several states spread across the country may be linked to the old Dentistry model based on merely curative and mutilating treatment, where the concern and care currently advocated were deprecated.

As for oral hygiene care, the use of toothbrush and toothpaste was present in $100 \%$ of the reports from caregivers. However, there was no description of oral hygiene care among completely edentulous people with no prosthetic rehabilitation, making it clear that, by the perception of caregivers, the absence of dental elements represents the needlessness of dental care. The use of other means of hygienization such as dental floss or oral antiseptic was also not referred by any of the caregivers, revealing precarious oral hygiene. Sá et al., for instance, confirmed that the lack of education and instruction causes mistakes such as the ones previously mentioned. Nevertheless, it was also verified that several professional caregivers recognize the importance of proper oral hygiene, but still many of them do not know how to do it properly, as verified in this study.

It is worth noting that dental biofilm accumulation leads to the destruction of both hard and soft tissues of the oral cavity. Moreover, inadequate oral hygiene may lead to the risk of developing oral cavity diseases such as caries, periodontitis, candidiasis, and stomatitis for the use of dentures, as well as halitosis (De Visschere et al., 2006). Cleaning with toothbrush, toothpaste, and 
dental floss is the basic hygiene procedure for dentulous patients and users of prosthesis, which should be cleaned and disinfected daily after each meal so the mucosa remains healthy (Moimaz et al., 2004). Oral hygiene of edentulous patients should also be performed daily by toothbrushing the tongue and cleaning the support tissues (palate, residual alveolar ridge, and jugal mucosa) with moistened gauze, and it may be complemented with the use of oral antiseptic (Saliba et al.).

Among the denture wearers, it was observed that most of them (44.4\%) cleans their prosthetic device once a day, while others do it twice $(22.2 \%)$, three times $(11.1 \%)$, or four times $(22.2 \%)$, revealing a divergence of attitude, and consequently, the lack of standardization and/or instruction regarding frequency and proper oral hygiene care, as well as knowledge or neglect about their importance to general health and quality of life of the elderly. Confirming this result, Wårdh et al., (2000) affirmed, through a qualitative study, that caregivers address low priority to oral care. Such fact could be solved by including a dentist in the minimum staff composing the LSIE, but also if the managers of these Institutions promoted the dental care recommended and were required to maintain oral health of the institutionalized elderly.

However, for being an extremely sensitive situation, some studies such as by Chiba et al. (2009), indicated the lack of cooperation from the elderly and the difficulties to access their mouths as the main reasons claimed by caregivers for inadequate oral hygiene. This shows the multifactorial aspect of care services as a reciprocity relation, where good interaction between the elderly and their caregivers is essential for the results obtained regarding health care. Again, the presence of the dentist is imperative, since they can take on the role of re-motivating and reeducating patients and caregivers regarding proper oral health care.

Despite the unsatisfactory results revealed by the present study regarding oral health care provided to the institutionalized elderly, most of the caregivers interviewed was satisfied with the oral health of the elderly $(75 \%)$ and the hygiene habits and methods they used (96.6\%); on the other hand, only $18.8 \%$ presented interest in learning new oral hygiene methods. Thus, an optimistic perception on oral health was observed, contrasting with precarious clinical condition and oral health care, with high prevalence on tooth losses and need for rehabilitating dental treatment.

\section{CONCLUSION}

In the light of the exposed facts, it is possible to conclude that caregivers of the elderly population investigated have an inadequate perception of oral health, and that oral hygiene care provided to the elderly with or without prosthetic rehabilitation is precarious. The need for multi-professional treatment to the elderly patient in long stay institutions was also observed. The presence of the dentist is a crucial factor for the maintenance of, especially, oral health. Monitoring and care services need to be restructured, promoting humanization and integrality. Moreover, it is required that caregivers are trained for the correct hygienization and oral health care, but also for general care to the elderly, so to improve their quality of life.

MARQUES, D. R.; MATOS, F. S.; SANTOS, T. M. L.; RODRIGUES, J. L. S. A.; PARANHOS, L. R.; MARTINS, F. \& VIEIRA DE ALMEIDA, J. R. Percepción de cuidadores sobre salud y cuidados de higiene oral de ancianos discapacitados institucionalizados. Int. J. Odontostomat., 10(3):443-448, 2016.

RESUMEN: Este estudio analizó la percepción de cuidadores sobre la salud oral de ancianos discapacitados asilados y los cuidados entregados en la higienización oral y frente a la rehabilitación protética. Se realizó un estudio observacional descriptivo, por medio de entrevistas con los respectivos cuidadores de los 32 ancianos seleccionados, institucionalizados en el Estado de Sergipe, Brasil. Todos los ancianos presentaban pérdidas dentales parciales (un $50 \%$ ) o totales (un $50 \%$ ) y solo el $28,1 \%$ hacía uso de prótesis dentaria removible. Los aparatos protéticos y dientes remanecientes de los ancianos se higienizaban solo con cepillo y crema dental (un $100 \%$ ), con frecuencias diarias divergentes entre los cuidadores, sin la orientación de un dentista. La mayoría de los cuidadores se mostró satisfechos con la salud oral del anciano (un $75 \%$ ) y (un 96,9\%) con el método de higiene oral que utilizaban, y no expresaron interés en conocer nuevos métodos (un $81,3 \%$ ). Se concluyó que los cuidadores tienen una percepción inadecuada sobre la salud oral de la población de ancianos investigada y que los cuidados de higiene oral entregados a los ancianos son precarios.

PALABRAS CLAVE: cuidado dental para ancianos, cuidadores, higiene oral, hogares para ancianos, salud oral.

\section{REFERENCES}

Almeida, L. F. F.; de Freitas, E. L.; Salgado, S. M. L.; Gomes, I. S.; Franceschini, S. C. C. \& Ribeiro, A. Q. Projeto de intervenção comunitária "Em Comum-Idade": contribuições para a promoção da saúde entre idosos de Viçosa, MG, Brasil. Cien. Saude Colet., 20(12):3763-74, 2015.

Benedetti, T. R. B.; Borges, L. J.; Petroski, E. L. \& GonçalvesI, L. H. T. Atividade física e estado de saúde mental de idosos. Rev. Saude Publica, 42(2):302-7, 2008. 
Carneiro, R. M. V.; da Silva, D. D.; de Sousa, M. L. R. \& Wada, R. S. Saúde bucal de idosos institucionalizados, zona leste de São Paulo, Brasil, 1999. Cad. Saude Publica, 21(6):1709-16, 2005.

Colussi, C. F.; de Freitas, S. F. T. \& Calvo, M. C. M. Perfil epidemiológico da cárie e do uso e necessidade de prótese na população idosa de Biguaçu, Santa Catarina. Rev. Bras. Epidemiol., 7(1):88-97, 2004.

Chiba, Y.; Shimoyama, K. \& Suzuki, Y. Recognition and behaviour of caregiver managers related to oral care in the community. Gerodontology, 26(2):112-21, 2009.

Costa, A. M.; Guimarães, M. C. M.; Pedrosa, S. F.; Nóbrega, O. T. \& Bezerra, A. C. B. Perfil da condição bucal de idosas do Distrito Federal. Cien. Saude Colet., 15(4):2207-13, 2010.

De Visschere, L. M.; Grooten, L.; Theuniers, G. \& Vanobbergen, J. $\mathrm{N}$. Oral hygiene of elderly people in long-term care institutions-a cross-sectional study. Gerodontology, 23(4):195-204, 2006.

Ferreira, R. C.; de Magalhães, C. S. \& Moreira, A. N. Tooth loss, denture wearing and associated factors among an elderly institutionalised Brazilian population. Gerodontology, 25(3):16878, 2008.

Ferreira, R. C.; de Magalhães, C. S.; Rocha, E. S.; Schwambach, C. W. \& Moreira, A. N. Saúde bucal de idosos residentes em instituições de longa permanência de Belo Horizonte, Minas Gerais, Brasil. Cad. Saude Publica, 25(11):2375-85, 2009.

Ferreira, R. C.; Schwambach, C. W.; de Magalhaes, C. S. \& Moreira, A. N. Atenção odontológica e práticas de higiene bucal em instituições de longa permanência geriátricas. Cienc. Saude Colet., 16(4):2323-33, 2011.

Ferreira, R. C.; Vargas, A. M.; Fernandes, N. C. N.; Souza, J. G. S.; de Sá, M. A. B.; Oliveira, L. F. B. \& Martins, M. E. B. L. O idoso com comprometimento cognitivo apresenta pior condição de saúde bucal? Cienc. Saude Colet., 19(8):3417-28, 2014.

Frare, S. M.; Limas, P. A.; Albarello, F. J.; Pedot, G. \& Régio, R. A. S. Terceira idade: quais os problemas bucais existentes? Rev. Assoc. Paul. Cir. Dent., 51(6):573-6, 1997.

Gaião, L. R.; de Almeida, M. E. L. \& Heukelbach, J. Perfil epidemiológico da cárie dentária, doença periodontal, uso e necessidade de prótese em idosos residentesem uma instituição na cidade de Fortaleza, Ceará. Rev. Bras. Epidemiol., 8(3):31623, 2005.

Haikal, D. S. A.; Paula, A. M. B.; Martins, A. M. E. B. L.; Moreira, A. N. \& Ferreira, E. F. Autopercepção da saúde bucal e impacto na qualidade de vida do idoso: uma abordagem quantiqualitativa. Cienc. Saude Colet., 16(7):3317-29, 2011.

Hopcraft, M. S.; Morgan, M. V.; Satur, J. G. \& Wright, F. A. Edentulism and dental caries in Victorian nursing homes. Gerodontology, 29(2):e512-9, 2012.

Instituto Brasileiro de Geografia e Estatística (IBGE). Síntese de indicadores sociais: uma análise das condições de vida da população brasileira. Estudos e pesquisas: informação demográfica e socioeconômica. São Paulo, Instituto Brasileiro de Geografia e Estatística, 2010. pp.191.
Mafra, S. C. T. A tarefa de cuidar e as expectativas sociais diante de um envelhecimento demográfico: a importância de ressignificar o papel da família. Rev. Bras. Geriatr. Gerontol., 14(2):353-63, 2011.

Maia, L. C.; Durante, A. M. G. \& Ramos, L. R. Prevalência de transtornos mentais em área urbana no norte de Minas Gerais, Brasil. Rev. Saude Publica, 38(5):650-6, 2004.

Magalhaes, K.A.; Giacomin, K.C.; Santos, W.J.; Firmo, J.O. A visita domiciliária do agente comunitário de saúde a famílias com idosos frágeis. Cien. Saude Colet., 20(12):3787-96, 2015.

Martins, A.M.; Jones, K.M.; Souza, J.G.; Pordeus, I.A. Associação entre impactos funcionais e psicossociais das desordens bucais e qualidade de vida entre idosos. Ciênc. Saude Colet., 19(8): 346178, 2014.

Moimaz, S.A.S.; Santos, C.L.V.; Pizzato, E.; Garbin, C.A.S.; Saliba, N.A. Perfil de utilização de próteses totais em idosos e avaliação da eficácia de sua higienização. Brazilian Dent. Sci., 7(3):72-8, 2004.

Pereira, R. J.; Cotta, R. M.; Franceschini, S. do C.; Ribeiro, R. C.; Sampaio, R. F.; Priore, S. E.; \& Cecon, P. R. The influence of sociosanitary conditions on the quality of life of the elderly in a municipality in the Southeast of Brazil. Cien. Saude Colet., 16(6):2907-17, 2011.

Reis, S. C. G. B.; Higino, M. A. S. P.; de Melo, H. M. D. \& Freire, M. C. M. Condição de saúde bucal de idosos institucionalizados em Goiânia-GO, 2003. Rev. Bras. Epidemiol., 8(1):67-73, 2005.

Reis, S. C.; Marcelo, V. C.; da Silva, E. T. \& Leles, C. R. Oral health of institutionalised elderly: a qualitative study of health caregivers' perceptions in Brazil. Gerodontology., 28(1):69-75, 2011.

Rigo, L.; Basso, K.; Pauli, J.; Cericato, G. O.; Paranhos, L. R. \& Garbin, R.R. Satisfação com a vida, experiência odontológica e autopercepção da saúde bucal entre idosos. Cien. Saude Colet., 20(12):3681-8, 2015.

Rosa, L. B.; Zuccolotto, M. C.; Bataglion, C. \& Coronatto, E. Odontogeriatria - a saúde bucal na terceira idade. Rev. Fac. Odontol. U. F. P., 13(2):82-6, 2008.

Sá, I. P. C.; de Almeida Júnior, L. R.; Corvino, M. P. F. \& Sá, S. P. C. Condições de saúde bucal de idosos da instituição de longa permanência Lar Samaritano no município de São Gonçalo-RJ. Cien. Saude Colet., 17(5):1259-65, 2012.

Saliba, C.A.; Saliba, N.A.; Marcelino, G.; Moimaz, S.A.S. Saúde bucal dos idosos: uma realidade ignorada. Rev. da Assoc. Paul. Cir., 53(4):279-82, 1999

Wårdh, I.; Hallberg, L. R.; Berggren, U.; Andersson, L.\& Sörensen, S. Oral health care--a low priority in nursing. In-depth interviews with nursing staff. Scand. J. Caring Sci., 14(2):137-42, 2000.

\section{Correspondence to:}

Luiz Renato Paranhos

Rua Jordão de Oliveira, 996, Apto 1402

Atalaia, ZIP Code: 49037-330

Aracaju, SE

BRAZIL

Received:04-05-2016

E-mail: paranhos.Irp@gmail.com
Accepted:20-09-2016 